\title{
Florida Plant Disease Management Guide: Sweet Basil'
}

\author{
Shouan Zhang, Geoffrey Meru, and Pamela D. Roberts ${ }^{2}$
}

\section{Downy Mildew (Peronospora belbahrii)}

Downy mildew is the most common and devastating disease of basil in the United States since it was first reported in south Florida in 2007. It occurs in both field- and greenhouse-grown basils as well as home gardens across the eastern US and Canada.

Symptoms: Symptoms initially appear as yellowing or chlorosis between veins on the upper side of the leaves, which can be easily mistaken for nutrient deficiencies. The discolored area may cover most of the leaf surface over time, and the affected leaves may curl and wilt. On the underside of leaves, a gray fuzzy growth of the pathogen may be apparent by visual inspection. Under high humidity, the chlorotic areas turn to dark brown quickly. Sporangia, the reproductive structures of the pathogen, are easily detected under magnification.

Cultural Controls: Selecting resistant basil varieties, which have been available on the market recently, can be an economical measure. Use disease-free seed as the pathogen is believed to be seed transmitted. Reducing the period of leaf wetness by avoiding overhead watering may also be helpful. Increase plant spacing to provide good air movement that allows leaves to dry quicker after irrigation or rain. Promptly remove and destroy any basil plants infected with downy mildew.

\section{Leaf Spot (Colletotrichum sp.)}

Symptoms: Dark brown to black spots form on leaves and the dead tissue within these spots may drop out, causing a shot-hole symptom. The disease can cause defoliation, tip dieback, stem lesions, and sometimes loss of entire plants. Spores can be water-splashed from diseased tissue to healthy plants.

Cultural Controls: Sow seed in sterilized soil or a soilless mix in sterile containers. Reduce periods of leaf wetness by reducing humidity and increase plant spacing to increase air movement. Avoid overhead irrigation. Remove diseased plants to reduce inoculum levels.

\section{Bacterial Leaf Spot (Pseudomonas cichorii)}

Symptoms: Spots on leaves are water-soaked and dark. They may be both angular and delineated by small veins in the leaves or irregular in shape. A wet stem rot may occur. The bacterium is reported to be seed-borne. The disease is favored by wet, humid conditions and is disseminated by splashing water or by handling infected tissue and then touching other plants.

Cultural Controls: Use disease-free seed and transplants. Decrease moisture on plants with low humidity and sufficient plant spacing for adequate air movement to reduce periods of leaf wetness. Avoid overhead irrigation. Remove

1. This document is PP-113, one of a series of the Plant Pathology Department, UF/IFAS Extension. Original publication date January 2003. Revised March 2009 and December 2021. Visit the EDIS website at https://edis.ifas.ufl.edu for the currently supported version of this publication.

2. Shouan Zhang, professor, Plant Pathology Department; Geoffrey Meru, assistant professor, Horticultural Sciences Department, UF/IFAS Tropical Research and Education Center; Pamela D. Roberts, professor, Plant Pathology Department, UF/IFAS Southwest Florida Research and Education Center; UF/IFAS Extension, Gainesville, FL 32611.

The Institute of Food and Agricultural Sciences (IFAS) is an Equal Opportunity Institution authorized to provide research, educational information and other services

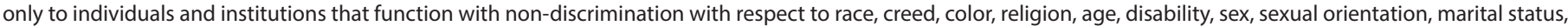

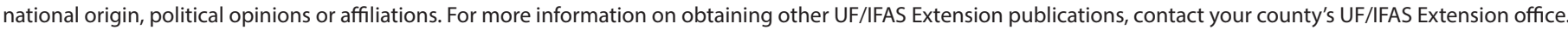
U.S. Department of Agriculture, UF/IFAS Extension Service, University of Florida, IFAS, Florida A \& M University Cooperative Extension Program, and Boards of County Commissioners Cooperating. Nick T. Place, dean for UF/IFAS Extension. 
diseased leaves and plants to reduce inoculum levels. Use clean, sterile equipment and do not move between infected and healthy plants.

\section{Fusarium Wilt (Fusarium oxysporum f. sp. basilici)}

Symptoms: Initial disease symptoms are yellowing of the shoots, distorted young leaves, and internal vascular discoloration of stems. As the disease advances, plants wilt and eventually die. The pathogen is seed-borne and can survive in the soil for many years.

Cultural Controls: Use resistant cultivars when possible- resistance has been reported in some basil cultivars. Use disease-free or disinfested seed in sterilized soil or a soilless mix. Rotate fields to another crop not susceptible to Fusarium. 